\title{
THE TRANSLATION RESULT EVALUATION OF NON- STANDARD ENGLISH SIMPLE SENTENCES (AFRICAN AMERICAN VERNACULAR ENGLISH) INTO INDONESIAN IN THE NOVEL ENTITLED THE HELP BY KATHRYN STOCKETT
}

\author{
Doni Anggoro Ari Santoso \\ Program of English Education, Faculty of Language and Art, University of Indraprasta PGRI \\ Jalan Nangka No. 58C Tanjung Barat, Jagakarsa, South Jakarta 12530 \\ don.okba@gmail.com
}

\begin{abstract}
This research is an overall view over translation of African American Vernacular English (AAVE) especially simple sentences in the novel The Help by an American author Kathryn Stockett and in the translation by Barokah Ruziati. The objectives of this research are: (1) to analyze the translation of simple sentences from Non-Standard English into simple sentences from Standard Indonesian; and (2) to analyze the result that accordance with good criteria of translation. This novel is written in Non-Standard English particularly AAVE and it is translated into Standard Indonesian. The writer analyzes simple sentences in the novel to figure out the quality of its translation. To analyze the data, the writer uses descriptive qualitative method. The writer analyzes descriptive data from simple sentences. The findings show that there is $63.29 \%$ of accurate translation and $36.70 \%$ of less accurate translation.
\end{abstract}

Key words: translation, African American Vernacular English, simple sentences

\begin{abstract}
ABSTRAK
Penelitian ini merupakan suatu pandangan menyeluruh terhadap penerjemahan bahasa Inggris Tidak Baku Afrika-Amerika (AAVE) terutama pada kalimat-kalimat tunggal dalam novel the Help karya penulis Amerika Kathryn Stockett dan diterjemahkan oleh Barokah Ruziati. Beberapa tujuan penelitian sebagai berikut: (1) untuk menganalisis penerjemahan kalimat-kalimat tunggal dari bahasa Inggris Tidak Baku ke dalam bahasa Indonesia Baku; (2) untuk menganalisis hasil penerjemahan yang sesuai dengan kriteria penerjemahan yang baik. Novel ini ditulis dalam bahasa Inggris Tidak Baku terutama AAVE dan diterjemahkan ke dalam bahasa Indonesia Baku. Penulis menganalisis kalimat-kalimat tunggal dalam novel untuk menganalisis kualitas penerjemahannya. Untuk menganalisis data, penulis menggunakan metode deskriptif kualitatif dengan data berupa kalimat-kalimat tunggal. Hasil temuan menunjukkan terdapat $63.29 \%$ data berupa penerjemahan yang akurat dan $36.70 \%$ mengandung penerjemahan yang tidak akurat.
\end{abstract}

Kata kunci: penerjemahan, AAVE, kalimat-kalimat tunggal 


\section{INTRODUCTION}

There are so many reading materials in various languages. One of the most popular reading materials or literature work in the world is the novel. Therefore, there are many novels are translated into various languages. For example, there are many novels in English that are translated into Indonesian language. In Indonesia, almost all novels are translated into Indonesian language become the bestseller novels. An example of a novel that becomes a bestseller novel in Indonesia is The Help by Kathryn Stockett.

Novel is one of the most popular literary works in the public. The novel itself is usually as a representation of a circumstance or event in a period time. People usually like to put their feelings and ideas into a novel. A novel presents to give an idea of the condition of a particular society. Besides that, novel is the representation not only the circumstance and event in a period time, but also as the representation of the language is used in a society.

In Indonesia, there are many novels translation from English. English itself is divided into two parts, namely standard and non-standard English. The language is used in the novel usually a standard language which is suitable with applicable rules like structural, grammatical rules for correct English. Trudgill (2000) mentions that Standard English is that variety of English which is usually used in print, and which is normally taught in schools and to nonnative speakers learning the language. It is also the variety which is normally spoken by educated people and used in news broadcasts and other similar situations.

However, in Kathryn

Stockett's novel The Help is an exception. In the novel, not only the standard language is used, but also most of the language is non standard language. Unlike standard language that has various rules such as grammar and structural, non-standard language does not have it. Non standard language is not proper and informal that is used as spoken language not in written. Non standard language itself has many examples, they are colloquial, pidgin, creole, jargon, slang, and vernacular. In this case, the type of non-standard language is used in The Help novel is vernacular. Holmes (2013:77) says:

"The term vernacular is used in a number of ways. It generally refers to a language which has not been standardized and which does not have official status. There are hundreds of vernacular languages, such as Buang in Papua New Guinea, Hindustani in India and Bumbar in Vanuatu, many of which have never been written down or described."

Besides which is mentioned above, there is another example of vernacular is African American Vernacular English (AAVE). At first, African American Vernacular English (AAVE) is created by black people in the USA. The black people (Afro-America) suffered for a long while America still embraces the system of slavery and discrimination against blacks in all fields. To counter this, they created something peculiar to their own creation to show the existence of a black community that is often discriminated against by white people in America. In addition, the use of AAVE may show their social background or regional background. Holmes (2013:188) describes as follows:

"In the USA, though their distinct languages disappeared centuries ago, African Americans do not need a distinct variety or code as a 
symbolic way of differentiating themselves from the majority group. They are visibly different. Nevertheless, this group has developed a distinct variety of English known as African American Vernacular English (I will use the abbreviation AAVE). This dialect has a number of features which do not occur in standard mainstream US English, and others which occur very much less frequently in the standard variety. These linguistic differences act as symbols of ethnicity. They express the sense of cultural distinctiveness of many African Americans."

As the writer said before that many novels in English are translated into Indonesian language. It aims to make it easier for Indonesian people to understand the novel, for those who do not master English well. Understanding a novel is not easy task. Therefore, the existence of translation is needed.

To solve problem for those people who do not have capability in understanding English well, translation is the correct way. According to Bell (1993:5), translation is referred to "The expression in another language (or target language) of what has been expressed in another, source language, preserving semantic and stylistic equivalences". Based on this statement, without translation, Indonesians especially who do not understand English well, may not be able to understand novel which is written in English. They will have difficulties and automatically will not get the message well.

Translation is the transfer of message from one language to others. In The Help novel, the language is used is African American Vernacular English (AAVE) which is a non-standard language, the novel is translated into Indonesian. But the interesting part is when AAVE is translated into Indonesian language, the language that is originally a non-standard, turns into standard language. There are both in grammatical and structural terms in Indonesian language.

It can be concluded that translation process does not only happen from standard language to standard language, but also happens from non standard language becomes standard language. All of these aims for the reader to understand the novel well. The process of translation novels from English to Indonesian language is supposed to pay attention to the use of non-standard of the source language (SL) into the target language (TL), in order to match the style that tends to be formal, objective, and standard. So, the reader receives the content of meaning and the message contained in the novel.

Each language has its own characteristics. For this reason, there cannot be an exact equivalent transfer of the source language into the target language, when the source language and the target language are widely different in the structural and cultural background. To rise above the differences in characteristics of these languages, a translator is required to comprehend the structure of both source and target languages. In other words, the translation is a complicated process involving both linguistic and non-linguistic problems. One part of the linguistic problems to be mastered by a translator is the structure, meaning the sequence of linguistic units that have connection to each other.

A translator has to be capable in mastering both English as source language (SL) and Indonesian language as target language (TL) structure when she or he translates English text into Indonesian. He or she will make them capable in understanding the meaning in the text accurately, and will allow them 
to transfer the same meaning appropriately and correctly using the suitable structure in the target language. Both English and Indonesian Language have differences both in their phonological and grammatical aspects. For example in the novel The Help by Kathryn Stockett which uses non standard English such as AfricaAmerican Vernacular English (AAVE). In the novel there are found many sentences that use non standard language, such as "You is kind", "She do not like" and so on. But when it translates into Indonesian language, the sentences become standard language like "Kamu anak baik", "Dia tidak suka".

Translation is defined in many ways by different writers in the field, depending on how they view language and translation. Larson (1998:3) explains:

"Translation is basically a change of form. When we speak of the form of a language, we are referring to the actual words, phrases, clauses, sentences, paragraphs, etc., which are spoken or written. These forms are referred to as the surface structure of a language. It is the structural part of language which is actually seen in print or heard in speech. In translation the form of the source language is replaced by the form of the receptor (target) language."

A standard language is usually based on the speech and writing of educated native speakers of the language, and it has the highest status in a community or nation. It is normally used in the literature, in the government documents, and in the news media. In addition, it describes in dictionaries and grammars, and uses in schools. Jenkins (2003:33) says:

"Standard language is the term used for that variety of a language which is considered to be the norm. It is the variety held up as the optimum for educational purpose and used as a yardstick against which other varieties of the language are measured. Being a prestige variety, a standard language is spoken by a minority of people within a society, typically those occupying positions of power."

A similar opinion is also presented by Holmes (2013:78) who says that "A standard variety is generally one which is written, and which has undergone some degrees of regularisation or codification (for example, in a grammar and a dictionary); it is recognised as a prestigious variety or code by a community, and it is used for $\mathrm{H}$ functions alongside a diversity of $\mathrm{L}$ varieties.

In contrast, non-standard language is opposite. It can be referred as vernacular. Holmes (2013:77) states:

"In a multilingual speech community, the many different ethnic or tribal languages used by different groups are referred to as vernacular languages. Vernaculars are usually the first languages learned by people in multilingual communities, and they are often used for a relatively narrow range of informal functions."

Vernacular is a non-standard language commonly used by ordinary people in a particular area or country and it uses in daily life. Holmes (2013:77) mentions that "There are three components of the meaning of the term vernacular. The most basic refers to the fact that a vernacular is an uncodified or unstandardized variety. The second refers to the way it is acquired in the home, as a first variety. The third is the fact that it is used for relatively circumscribed functions." 
The use of AAVE can show the social class of the speakers as Wardhaugh (2006:342) describes that "At first, after the abolition of slavery for black people, this triggers the rise of immigration from Europe, they come to America and then forms new communities and the most prominent are blacks". Accordingly, Lanehart (2001:23) states as follows:

"After the abolition of slavery and with increasing immigrations from Europe, different forms and degrees of segregation inversely correlated with different degrees of integration within the dominant Englishspeaking White community have taken place in North America, the most conspicuous of which has been that of Blacks."

Moreover, Trudgill (2000:65) affirms that "The term AAVE is generally used to refer to the nonstandard English spoken by lower-class African Americans". As a nonstandard language, AAVE has its own special characteristics which make it be different with another nonstandard language. One of the characteristic is omission of verb be and distinct meanings of be as Holmes (2013:188) states that:

"AAVE is heard especially in the northern cities of the USA. One of its most distinctive features is the complete absence of the copula verb be in some social and linguistic contexts. In most speech contexts, speakers of standard English use shortened or reduced forms of the verb be."

\section{METHOD}

This research uses descriptive qualitative method. Descriptive analysis means to analyze the data which describes the research based on the fact taken from the novels. The research deals with a research procedure that generates descriptive data in the sentence forms, specifies in simple sentences. According to Punch (2014:3) "Qualitative research is empirical research where the data are not in the form of numbers". Subjects or data sources are all information that are collected and chosen by the research.

The writer uses two novels as his primary sources. They are novels entitled The Help by Kathryn Stockett and its translated version by Barokah Ruziati. This novel consists of 34 Chapters and 444 pages. It is published in 2009 and translated into Indonesian in 2010. This research is conducted to analyze the simple sentences found in the English novel version. Additionally, this research uses supporting data that is taken from education books and relevant theories.

\section{RESULTS AND DISCUSSION}

This research is aimed to analyze the simple sentences found in the novel, to figure out the principles of translation and to evaluate the quality of translation of Indonesian version in terms of accuracy, clarity, and naturalness used in translating the novel entitled "The Help" by Kathryn Stockett. Accuracy means that the translator should deliver the appropriate information or message as intended by the writer in the source text (SL). Clarity means that the translation should be understood easily by the readers. Naturalness means the translation should not sound strange so that it is intended to be easier to read by the readers from the target language. The writer decides the effectiveness based on those standards.

\section{The Accurate Translation}

Datum 1:

SL: I done raised seventeen kids in my lifetime. (Stockett: 1)

TL: Seumur hidup aku sudah membesarkan tujuh belas anak. 
(Ruziati: 5)

Both SL and TL show simple sentences, because there is an independent clause (SL: I done raised seventeen kids in my lifetime, TL: Seumur hidup aku sudah membesarkan tujuh belas anak). There is one subject I and one verb done raised in SL. Then, one subject $a k u$ and one verb sudah membesarkan in TL. The translation can be understood easily and makes sense, since there are not difficult words to be comprehended. Furthermore, the accuracy, clarity, and naturalness have the high level.

Datum 2:

SL: Miss Leefolt, she look terrified her own child. (Stockett: 1)

TL: Miss Leefolt, dia tampak takut menghadapi anaknya sendiri. (Ruziati: 5)

The two sentences above indicate that both of SL and TL are simple sentences, since the sentences have one independent clause, (SL: Miss Leefolt, she look terrified her own child, TL: Miss Leefolt, dia tampak takut menghadapi anaknya sendiri). Furthermore, there is a subject she and a verb look terrified in SL. And there is a subject dia and a verb tampak takut in TL. The meaning of the translation is understandable and the quality of the translation is good viewed from the accuracy, clarity, and naturalness.

Datum 3:

SL: But Miss Leefolt, she don't pick up her own baby for the rest a day. (Stockett: 1)

TL: Tapi Miss Leefolt, dia tidak menyentuh bayinya lagi sepanjang hari itu. (Ruziati: 5)

As seen the datum above, the SL and TL are simple sentences, since the sentences have an independent clause, (SL: But Miss Leefolt, she don't pick up her own baby for the rest a the day, TL: Tapi Miss Leefolt, dia tidak menyentuh bayinya lagi sepanjang hari itu). There is one subject she and one verb don't pick up in SL. Next, there is one subject dia and one verb tidak menyentuh in TL. The translation can be understood well and the quality of the translation is good viewed from the accuracy, clarity, and naturalness.

Datum 5:

SL: Her face be the same shape as that red devil on the redhot candy box, pointy chin and all. (Stockett: 2)

TL : Bentuk wajahnya mirip iblis merah di kotak permen Redhot, dengan dagu lancip dan semuanya. (Ruziati: 6)

The two sentences above indicate that both of SL and TL are simple sentences, since the sentence has one independent clause, (SL: Her face be the same shape as that red devil on the redhot candy box, pointy chin and all, TL: Bentuk wajahnya mirip iblis merah di kotak permen Redhot, dengan dagu lancip dan semuanya). It can be seen on the sentence there is a subject her face and a verb be the same shape in SL. Then, there is a subject bentuk wajahnya and a verb mirip in TL. The quality of the translation is understandable and clear. Moreover, the translator uses a good way to translate the text.

Datum 8:

SL: They kind a favor except Mae Mobley so fat. (Stockett: 2)

TL: Mereka berdua memang mirip, hanya saja Mae Mobley sangat gemuk. (Ruziati: 6)

The SL and TL show simple sentences. The indication is both have one independent clause, (SL: They kind a favor except Mae Mobley so fat, TL: Mereka berdua memang mirip, hanya saja Mae Mobley 
sangat gemuk). This sentence has one subject they and one verb favor in SL and one subject mereka berdua and one verb mirip in TL. The meaning of translation is correct and the translation is equipped of the criteria of a good translation.

Datum 9:

SL: She ain't gone be no beauty queen. (Stockett: 2)

TL: Dia tidak akan menjadi ratu kecantikan. (Ruziati: 6)

Both sentences (SL and TL) are simple sentences, since the sentences consist of one independent clause (SL: She ain't gone be no beauty queen, TL: Dia tidak akan menjadi ratu kecantikan). Since there is one subject she and one verb ain't gone be no in SL. Next, there is a subject dia and a verb tidak akan menjadi in TL. The translation is accurate and it is easy to be understood because the translator uses the good way to translate the text.

Datum 10:

SL: He had him a little apartment over on Foley Street. (Stockett: 2)

TL: Dia memiliki apartemen mungil di Foley Street. (Ruziati: 6)

The two sentences above indicate that both of SL and TL are simple sentences, since the sentence consists of one independent clause, (SL: He had him a little apartment over on Foley Street, TL: Dia memiliki apartemen mungil di Foley Street). The sentence has one subject he and one verb had in SL. In addition, it also has one subject dia and one verb memiliki in TL. In this translation, the translator can deliver the message to the readers clearly. It is a good translation and understandable.

Datum 11:

SL: He even start writing his own book, bout being a colored man living and working in Mississippi. (Stockett: 2)

TL: Dia bahkan mulai menulis bukunya sendiri, tentang menjadi pria berkulit hitam yang tinggal dan bekerja di Mississipi. (Ruziati: 6)

The two sentences above indicate that both of SL and TL are simple sentences, since the sentences consist of an independent clause, (SL: He even start writing his own book, bout being a colored man living and working in Mississippi, TL: Dia bahkan mulai menulis bukunya sendiri, tentang menjadi pria berkulit hitam yang tinggal dan bekerja di Mississipi). This sentence has one subject he and one verb start writing in SL. Besides, there is one subject dia and one verb mulai menulis in TL. The translator chose good words to translate it so that there is no problem in the meaning of translation.

Datum 12:

SL: He slip off the loading dock, fell down on the drive. (Stockett: 2)

TL: Dia terpeleset dari dok pemuatan, jatuh ke jalan. (Ruziati: 7) Those sentences above are simple sentences. Since the sentence consists of an independent clause, (SL: He slip off the loading dock, fell down on the drive, TL: Dia terpeleset dari dok pemuatan, jatuh ke jalan). There is a compound verb in a simple sentence or one subject he and two verbs slip off and fell down in SL. Other than that, there is one subject dia and two verbs terpeleset and jatuh in TL. The translator did the translation by using word-for-word translation so that in the translation, from the SL to the TL is obviously clear. The readers can get the message from it because it is a communicative translation.

Datum 20:

SL: She pretty good with the sewing 
machine. (Stockett: 4)

TL: Dia sangat pandai menggunakan mesin jahit. (Ruziati: 8 )

There is an independent clause that shows both SL and TL are simple sentences. (SL: She pretty good with the sewing machine, TL: Dia sangat pandai menggunakan mesin jahit). There is one subject she but there is no verb, since African American Vernacular English (AAVE) is used in SL. But it does not happen in TL. There is one subject dia and one verb menggunakan. When the sentence is translated into TL, it changes to standard language. This is a proof that the translation has the criteria of a good translation such as accuracy, clarity, and naturalness.

Datum 25:

SL: See, Miss Leefolt, she dress up nice every day. (Stockett: 4)

TL: Miss Leefolt, dia berdandan rapi setiap hari. (Ruziati: 9)

Both SL and TL show simple sentences, because there is an independent clause (SL: See, Miss Leefolt, she dress up nice every day, TL: Miss Leefolt, dia berdandan rapi setiap hari). The two sentences have one subject and one verb. There is she as a subject and dress up as a verb in SL. And there is dia and berdandan as a verb in TL. The translation makes sense and can be understood well, since there are not difficult words to be comprehended. The accuracy, clarity, and naturalness have the high level in this translation.

Datum 30:

SL: Today, since it's so hot, she wearing a red sleeveless dress with no waist to it. (Stockett: 5)

TL: Hari ini, karena cuaca sangat panas, dia menggenakan gaun tanpa lengan berwarna merah yang tak berpinggang. (Ruziati: 10)

The two sentences above show that they are simple sentences, each of them has an independent clause (SL: Today, since it's so hot, she wearing a red sleeveless dress with no waist to it, TL: Hari ini, karena cuaca sangat panas, dia menggenakan gaun tanpa lengan berwarna merah yang tak berpinggang). It can be seen that both in SL and TL there is one subject she and one verb wearing in SL. Moreover there is one subject dia and one verb mengenakan in TL. African American Vernacular English (AAVE) that is used in SL changes into standard language in Indonesian. This approves that the quality of translation is good and fulfills the criteria of a good translation.

Datum 35:

SL: They talking bout the help. (Stockett: 6)

TL: $\quad$ Mereka membicarakan pembantu. (Ruziati: 12)

Both sentences (SL and TL) are simple sentences, since the sentences consist of one independent clause (SL: They talking bout the help, TL: Mereka membicarakan pembantu). Both of sentences have one subject they and one verb talking in SL. One subject mereka and one verb membicarakan in TL. The translation is accurate and it is understandable.

Datum 40:

SL: Miss Skeeter, she frowning at Miss Hilly. (Stockett: 9)

TL: Miss Skeeter, dia mengerutkan dahi pada Miss Hilly. (Ruziati:14)

Those sentences are simple sentences with one subject she and one verb frowning in SL. Then there is one subject dia and one verb mengerutkan dahi in TL. Both of SL and TL are simple sentences (SL: Miss Skeeter, she frowning at Miss Hilly, TL: Miss Skeeter, dia mengerutkan dahi pada Miss Hilly). 
In the translation, from the SL to the TL is clearly that the translator does the translation by using word-forword translation. The readers get the message from it and it is a communicative translation. This category can be found in datum:

$\begin{array}{ccccccc}1 & 2 & 3 & 5 & 8 & 9 & 10 \\ 11 & 12 & 20 & 25 & 30 & 35 & 40\end{array}$

\section{b. The Less Accurate Translation}

\section{Datum 4:}

SL: Twenty-three years old and she lanky as a fourteen-year-old boy. (Stockett: 1)

TL: Usianya 23 tahun dan tubuhnya seramping bocah empat belas tahun. (Ruziati:6)

The two sentences above indicate that both of SL and TL are simple sentences, since the sentence consists of one independent clause (SL: Twenty- three years old and she lanky as a fourteen-year-old boy, TL: Usianya 23 tahun dan tubuhnya seramping bocah empat belas tahun). It can be seen that there is a subject she and no verb, since the SL is African American Vernacular English which is it omits copula verb be. The translation of the first sentence in SL sounds strange because the translator seemed to adopt the SL form. It becomes less-accurate and sound less-natural. It should be translated by replacing the sentence and adding a word or more so that makes the translation sounds natural. The correct translation is "Dia berusia 23 tahun dan tubuhnya kurus seperti anak berusia empat belas tahun." The additional words are "dia", "seperti" and "berusia". Besides that, the replace words are "berusia", "kurus", "anak".

Datum 18:

SL: I spec this is the smallest house I ever worked in. (Stockett: 3 )
TL: Kurasa ini rumah paling kecil yang pernah ku layani. (Ruziati: 8)

The two sentences above are simple sentences with one independent clause (SL: I spec this is the smallest house I ever worked in, TL: Kurasa ini rumah paling kecil yang pernah $\mathrm{ku}$ layani). There is one subject I and one verb spec in SL. The translation is less accurate since there is the use of less corrected word "kurasa". Besides that, in order to increase the accuracy of translation, there should be some addition of words such as "selama aku bekerja". Therefore, the translation should be "Aku rasa ini adalah rumah terkecil yang pernah $\mathrm{ku}$ layani selama aku bekerja".

Datum 19:

SL: Miss Leefolt done the house up nice as she can. (Stockett: 4)

TL: Miss Leefolt mendandaninya secantik mungkin. (Ruziati: 8)

Two sentences above indicate that both of SL and TL are simple sentences. Both of them consist of one independent clause, (SL: Miss Leefolt done the house up nice as she can, TL: Miss Leefolt mendandaninya secantik mungkin). There is one subject Miss Leefolt and one verb done up in SL, and there is one subject Miss Leefolt and one verb mendandaninya in TL. The translation of the sentence in SL is lacking exactness and accuracy of detail. It happens when the translator changes the phrase "done the house up" to a word "menata". The translator uses imprecise words to translate the phrases. It should be "Miss Leefolt menata rumahnya sebagus yang dia bisa".

Datum 26:

SL: He scratch his head. (Stockett: 5)

TL: Dia menggaruk kepala. (Ruziati: 10)

The two sentences above are simple 
sentences, (SL: He scratch his head, TL: Dia menggaruk kepala). There is a subject he and a verb scratch in SL. Then there is a subject dia and a verb menggaruk in TL.

The translation is less accurate because in TL there is no repetition of word "menggaruk" it should be "menggaruk-garuk" so that it sounds more natural. Besides that, the translator does not translate the word "his" in TL. The word "his", should be translated as affix "nya" to show the possessive. Lastly, the translation should be "Dia menggaruk-garuk kepalanya".

Datum 27:

SL: Plus he the greasiest no-count you ever known. (Stockett: 5)

TL: Ditambah lagi dia manusia tak berharga paling menjijikan yang pernah kau kenal. (Ruziati: 10)

It can be seen that the two sentences above are simple sentences. (SL: Plus he the greasiest no-count you ever known, TL: Ditambah lagi dia manusia tak berharga paling menjijikan yang pernah kau kenal). There is one subject he and no verb because the language in SL is African American Vernacular English. The translation is less accurate. The translator should put conjunction and verb in order to make the translation more accurate and sounds natural. The right conjunction is "yang" and "dan" and the right verb is "adalah". Eventually, the accurate translation should be "Ditambah lagi dia adalah manusia tidak berharga dan paling menjijikan yang pernah kau temui". Datum 28:

SL: And then on Miss Leefolt's right be Miss Skeeter. (Stockett: 5)

TL: Dan di sebelah kanan Miss Leefolt, duduk Miss Skeeter. (Ruziati: 10)

Those sentences are simple sentences
(SL: And then on Miss Leefolt's right be Miss Skeeter, TL: Dan di sebelah kanan Miss Leeflot, duduk Miss Skeeter). In that sentence there is one subject Miss Leefolt's right and one verb be in SL. There is one subject Miss Leeflot and one duduk. The translation is less accurate, it should be "Miss Skeeter duduk di sebelah kanan Miss Leefolt". The phrase "right be" in SL is translated into phrase "duduk di sebelah kanan" in TL.

Datum 38:

SL: She my boss. (Stockett: 8)

TL: Dia majikan ku. (Ruziati: 14)

The sentences above are simple sentences consisting of an independent clause, (SL: She my boss, TL: Dia majikan ku). There is one subject she and not any verb in SL, since the SL uses African American Vernacular English (AAVE). Then there is one subject dia and no any verb in TL. The translation is less accurate and it is not clear. Even though the SL uses AAVE as its source language but the translation should be standard Indonesian language. There is should be an addition word "adalah" as a verb in TL, so that not only more accurate and clear, the translation sounds natural. It should be "Dia adalah majikan $k u^{\prime \prime}$.

Datum 41:

SL: Miss Hilly raise an eyebrow. (Stockett: 9)

TL: Miss Hilly menaikkan alis. (Ruziati: 15)

The two sentences above are simple sentences, since there is only one independent clause, (SL: Miss Hilly raise an eyebrow, TL: Miss Hilly menaikkan alis). There is one subject Miss Hilly and one verb raise in SL, besides there is one subject Miss Hilly and one verb menaikkan in TL. The 
translation is less accurate and does not sound natural. The translator does not translate it well. The phrase "raise an eyebrow" should be translated into "menaikkan sebelah alisnya". It is more accurate and sounds natural. In addition, the readers can get the meaning easily. So the translation should be "Miss Hilly menaikkan sebelah alisnya".

The data belong to this category are as follows:

$\begin{array}{llll}4 & 18 & 19 & 26 \\ 27 & 28 & 38 & 41\end{array}$

\section{CONCLUSION}

Translation is not an easy job. It involves several things that must be fulfilled. The examples are the selection of the right words and equivalent. In addition, to be a good translation, it must have several testing. The main purpose of the testing is to make sure that the translation fulfils the criteria of a good translation. A good translation should fulfill three criteria such as accuracy, clarity, and naturalness (Larson, 1998:529). Accuracy means that the translator should deliver the appropriate information or message as intended by the writer in the source text (SL). Clarity means that the translation should be understood easily by the readers. Naturalness means the translation should not sound strange so that it is intended to be easier to read by the readers from the target language.

This novel uses African American Vernacular English (AAVE) as its language. AAVE itself is a nonstandard language that rarely used for novels generally. However, the interesting part is when the novel is translated into Indonesian, it becomes standard Indonesian language. Besides that, it fulfills of a good criteria of translation. The translation of this novel can be categorized into a good translation in discussion. It has $63.29 \%$ from 79 data taken from the novel both English version and Indonesian version that has met the criterias of good translation (accuracy, clarity, and naturalness). Whereas only $36.70 \%$ hasn't met the criterias. Based on the result, it can be seen that the writer has to pursue the field of translation, a good translator must be fluent at least two languages and the level of the language skill must be quite high. A professional translator must be intelligent, intellectually curious and open minded. A good translator should pay attention about the result of his or her work, so that it has a good quality of translation. Therefore, a translator must check his or her work carefully before it is published.

\section{REFERENCES}

Bell, R. T. (1993). Translation and Translating: Theory and Practice. USA: Longman, Inc.

Holmes, J. (2013). An Introduction to Sociolinguistics. 4th. ed. New York: Routledge.

Jenkins, J. (2003). World Englishes: A Resource Book for Students. 2nd. $e d$. New York: Routledge.

Lanehart, S. L. ed. (2001). Sociocultural and Historical Contexts of Africa and American English. Amsterdam: John Benjamins Publishing Company.

Larson, M. L. (1998). Meaning-Based Translation: A Guide to CrossLanguage Equivelence. USA: University Press of America, Inc.

Punch, K. F. (2014). Introduction to Social Research: Quantitative and Qualitative Approaches. London: SAGE Publications Ltd.

Trudgill, P. (2000). Sociolinguistics: An Introduction to Language and Society. 4th. ed. London: Penguin Books. 
Wardhaugh, R. (2006). An Introduction to Sociolinguistics. 5th. ed. USA:

Blackwell Publishing Ltd. 